\title{
Meaning(s) of Otakar Zich's Concept of the 'Semantic Image'1
}

\author{
Dita Lánská
}

Otakar Zich (1879-1934) was one of the leading personalities in the field of aesthetics in the Czech lands (later Czechoslovakia). As far as can be ascertained, he was the first Czech theoretician to use the term 'semantic image' in their work on aesthetics. Many researchers $^{2}$ were interested in his definition of the 'semantic image'. Zich's definition of the term changed over time, as will be shown through his writings and teachings. Zich distinguished between an art work's perception and its structure, by using two terms: the (actor's) 'figure' and the 'dramatic person'. This distinction shifted his thinking regarding theatrical semantics. In his review of Zich's key work, The Aesthetics of Dramatic Art (Estetika dramatického umění), Jan Mukařovský interprets Zich as an 'intuitive' semiotician. He wrote: 'This "semantic image" of his is in fact just a complex, multi-leveled meaning’ (MUKǍ̌OVSKÝ 1933: 318-9). Later, Ivo Osolsobě, another theoretician, also regarded Zich as a semiotician.

Following his three main theoretical works devoted to three different art forms, this study focuses primarily on Zich's changing understanding of the 'semantic image'. Zich introduced the term at the very beginning of his career, namely in his habilitation thesis

\footnotetext{
1 This paper was created upon revising the author's master thesis.

2 Zich's works are commented on to this day. These are the most significant commentators: Oleg Sus, who summed up his research in the book 'Geneze sémantiky hudby a básnictví v moderní české estetice. Dvě studie o Otakaru Zichovi' (Genesis of Semantics of Music and Poetry in Modern Czech Aesthetics: Two Studies on Otakar Zich; SUS 1992). It is necessary to mention Sus's preface to the reprint of The Aesthetics of Dramatic Art which was published under the title 'Průkopník české strukturně sémantické divadelní vědy (Psychosémantika a divadelní umění)' (Pioneer of Czech Structural-Semantic Theatre Studies [Psychosemantics and Theatre]) in German Würzburg in 1977 (reprint in Theatralia 13 (2010): 2: 218-243).

Ivo Osolsobě interpreted Zich's work in terms of his semiotic thinking about theatre: 'Sémiotika sémiotika Otakara Zicha' (The Semiotics of Otakar Zich, a Semiotician; OSOLSOBĚ 1981), 'Herecká postava - pro a proti' (Actor's Figure - pros and cons; OSOLSOBĚ 2007) or epilogue in the second edition of The Aesthetics of Dramatic Art entitled 'Zichova filozofie dramatického tvaru' (Zich's Philosophy of Drama; OSOLSOBĚ 1986). Together with Miroslav Procházka, he wrote an extensive commentary to this book. Miroslav Procházka also dealt with Zich in texts 'O povaze dramatického textu' (On the Nature of Dramatic Text; PROCHÁZKA 1988a) and 'U základo̊ sémiotiky divadla' (The Roots of Theatre Semiotics; PROCHÁZKA 1988b).
} 
called Aesthetic Perception of Music (Estetické vnímáni hudby) (1910). In his second work, The Types of Poetry (O typech básnických) (1918), Zich defined his view of poetics and offered a modified meaning of the term 'semantic image'. Shortly before his death, Zich published The Aesthetics of Dramatic Art (1931), a study crucial for any later theoretical research in the field of drama and theatre.

The methodology used in Aesthetic Perception of Music is clearly influenced by Otakar Hostinský (1847-1910), Zich's teacher and predecessor; therefore, its aesthetics tend to be much more experimental and/or psychological. Based on experimental research, Zich also aimed to demonstrate the validity of a theory regarding the psychological perception of music, which he termed 'semantic image'.

Zich's The Types of Poetry is again focused on the psychology of aesthetic perception, namely of poetry. The book offers a typology of poems and poets alike, which is based on human tendency to (unconsciously) prefer a certain type of perception.

Finally, The Aesthetics of Dramatic Art has provided us with a complex system of Zich's drama and theatre theory. Zich systematically uses the term 'dramatic art' instead of 'theatre' in his book. Certain theatre forms do not correspond to the central concept of his theory - dramatic power, which is the key characteristic of drama and opera, his field of study.

\section{'Semantic image' in general}

Zich did not offer a clear definition of the term he adopted from Johannes Volkelt. Zich took its meaning for granted. According to him, 'semantic image' has more of a general meaning. In Aesthetic Perception of Music, Zich therefore speaks about semantic images generally in arts:

Am I to watch for instance an image of still-life, I perceive colourful splashes and their boundaries - shapes. Thus, a question arises: what do these percepts mean? [emphasis, $D L$ ] I realize: this is a grape of wine; that is a dead rabbit, etc. Even if there is no such evidence, I have a semantic image of certain kind: vegetables, flowers, birds etc. [...] We cannot speak about one semantic image, we are rather forced to capture a complex idea centred around one particular image [...]. (ZICH 1981: 156) ${ }^{3}$

Asking 'What do perceptions mean?' in order to define the semantic meaning makes Zich more of a semiologist.

The Aesthetics of Dramatic Art offers a broader understanding of the term, which is connected here to non-aesthetic reality; thus, Zich's interpretation does not only link to aesthetics: 'Every stable percept creates a certain mental sign in terms of similarity. This mental sign answers the basic question:

'What is it?' [emphasis, $D L]$; what do we hear, or see. We therefore call it a mental image. This image does not origin outside; it is mental-based and depends on our previous 
experience, which can make it general, casual, and pure, or unique, concrete, and rich. (ZICH 1986: 42)

Zich's characteristic, as offered in The Aesthetics of Dramatic Art, thus differs from that in Aesthetic Perception of Music. He does not ask 'what does an image mean?' but 'what is an image?'. This shift might be caused by the fact that in Aesthetic Perception of Music, Zich based the semantic meaning and its definition strictly on the perception of artworks, which is generally based on semiosis. Whereas The Aesthetics of Dramatic Art, includes images based on everyday reality and perception of objects, subjects, or actions in their broader, non-artistic sense. Both Oleg Sus (SUS 1992: 36) and Ivo Osolsobě (OSOLSOBĚ 2007) inclined to interpret semantic image in its semiotic sense.

All three theoretical systems I focus on, include the use of 'semantic image' as a term. Zich pointed out the specificity of each art form; therefore, his distinction of semantic images is influenced by the art form he was occupied with at that moment. His view was also influenced by his growth and development as a scholar-author. The period between his first and last study was approximately 20 years.

\section{Aesthetic Perception of Music (1910)}

Zich based Aesthetic Perception of Music on a simple experiment: respondents listened to passages of piano music and were then asked to answer several questions. The questions crucial for this article were: 'What kind of feeling and/or mood does this music have in your opinion?' and 'If you can't express it with words, feel free to compare it to anything you know from your everyday life, nature, or arts'(ZICH 1981: 61).

These questions show that Zich's interest belonged to the field of music semiology, which he pioneered in the Czech lands. His first question consciously focuses on both feeling and mood. Zich denied any possibility for non-musical meanings to be expressed by means of music, as music is incapable of expressing anything else than music itself. His second question provokes the participants to perform a contradictory action; they should try to describe the way they have perceived the piece of music via associations and non-musical images. The replies to the second question relate to non-musical associations however, and Zich did not accept these as a part of aesthetic perception.

It was their randomness which caused non-musical images to become unpopular with music aestheticians. Recipients' reactions, in form of subjective psychological processes, are incompatible with the demand on scientific accuracy, as the empirical field of aesthetics proclaimed about itself. Such a demand can be seen in Aesthetic Perception of Music too: 'It is obvious that these associations are completely vague, e.g. one cannot expect this or that reaction to a particular piece of music.' (ZICH 1981: 186) Besides their individuality, Zich also criticised their non-music character: 'Their development is neither systematic (e.g. does not follow any regularity) nor is it based on the disposition of an art work; thus, they corrupt its unity. Let an ideal percept be simply musical and its representation purely oral, just like it is represented only in time (and not in space).' (ZICH 1981: 187) 
In Aesthetic Perception of Music, Zich distinguishes between two associative principles leading the process of associating in the receiver's mind: similarity and contemporaneity (i.e. happening at the same time). Aural similarity allowed him to identify associations linked to human speech, natural sounds, or life events in the responses. According to Zich, aural associations are accompanied with kinaesthetic associations such as someone's movements or spatial propositions. Contemporaneity is then divided into general associations (based on convention), and individual associations.

František Krejčí, a Czech positivist philosopher and psychologist, was one of Zich's teachers. Both Otakar Hostinský and František Krejčí were highly influenced by, 'Herbartian formism', associative psychology, and the teachings of Wilhelm Wundt. Krejčí refused to accept 'soul' as a term, much like 'unconscious cognition', as well as any ability to experience transcendence. For these reasons, his system has often been called 'psychology without a soul'. It was Rudolf Pečman who pointed to Zich's inspiration derived from Krejčí and his works. According to Pečman, Zich's theory of semantic images is rooted in Krejčí's inclination towards associative psychology. Pečman argues:

Zich was familiar with Krejčí and his Associative Law even in his early writing period. He thought deeply of it; thus, Krejčí can be felt in Zich's writing. Neither Zich nor Krejčí conceived association in a simplified way [...]. Their concept of associative thinking was linked to a rich and broad sphere of human sentiment.' (PEČMAN 2008: 29)

Psychological analysis of aesthetic perception was the subject of contemporary scholarship. Zich defines musical perceptions as musical sounds - tones - and their complexes, which are bound by certain rules. Music, in its temporary duration, is composed of a number of tones, and exists in the form of created melody, which has the ability to evoke certain images. The perception in general goes hand in hand with the reproductions of images added to the percepts. This reproduction is based on the recall of mental contents. Complex perception is then perfected with the so-called mental image. As already mentioned, Zich refused to add semantic images of non-musical character to the aesthetic perception, such as associations to objects, subjects, action, or nature. In doing so, he limited himself to musical semantic images. He does admit, however, that music can have the ability to provoke emotions and/or moods.

Such strictly musical connotations and their potential semantic meanings as constituted by Zich in Aesthetic Perception of Music were treated by Oleg Sus (SUS 1992). Sus points to the fact that: if perceived in its purely musical meaning, music would only bear the meaning of itself. That would be a case of auto-designation, which lacks a crucial part of any device with a semantic function - to mean something else. He therefore perceived Zich's musical semantic images as a part of 'autosemantics' or immanent semantics.

In Aesthetic Perception of Music, Zich defined three basic types of musical semantic images: 'material' (věcnê), 'thematic' (látkové) and 'technical' (technické). He saw the 'material semantic image' (i.e. musical images) as musical individualities: a concrete melody, harmony, and rhythm. He identifies them with a musical theme or motif. 'Thematic 
semantic image' (i.e. sound) blends with the material image as a structural element of the art work. We speak about tones in their factuality and their specific characteristics (Zich mentions absolute pitch, instrumental diversity, and tone intensity). Technical semantic image is superior to the two previously mentioned: it may include either material or a thematic semantic image. It arises from the abstraction of concrete semantic images. These technical semantic images belong to the architectonics and structure of a musical piece.

Zich offers a long list of technical semantic images; he especially points to those mentioned by the respondents in his experiment. The list includes the following responses:

An anthem, dance in general, minuet [...] songs in general, a folk tune, a pastoral, a lullaby, a march [...] choir music, requiem, Smetana's compositions [...] gradation, tremolo, melody, musical interpretation, trebles [...] basses [...] tone repetitions, dissonance, moll, organ, harp [...] Taken from individual musical semantic images: Austrian anthem, a particular folk tune. (ZICH 1981: 173)

The diversity of all the listed items is obvious. They vary from dance to songs, be they concrete examples or general conceptions; the list includes various melodic elements as well as individual instruments and even particular compositions and composers.

Besides respondents' mental reactions to music perception, Zich was also interested in their physical reactions. In other words, he observed their motoric reactions to music. These included the movements caused by music, such as impulses or tendencies to move, as well as breathing and how it changed with musical stimulus. Zich called these motoric reactions 'internal-haptic perception': 'A motoric impulse in the form of muscular sensation can be seen very often, mainly as a reaction to music and accompanied either with a real movement or a tendency of the body to do so. The emotion of such internal-haptic perception is usually positive.' (ZICH 1981: 195) Zich connects this aspect of aesthetic perception to a contemporary theory of empathy and James-Lang's theory. Further in this article, it will be shown that Zich also observes kinaesthetic sensations as a reaction to poetry and drama/theatre.

\section{Johannes Volkelt (1848-1930)}

It is a known fact in the field that Zich adopted the term 'semantic image' from German philosopher Johannes Volkelt (1848-1930). Namely, from the first part of his System der Ästhetik (VOLKELT 1905). As the connection between Zich and Volkelt has been already examined (OSOLSOBĚ 1981, 1986; SUS 1958, 1992; KAISER 1993), it will be focused on here only briefly.

Volkelt distinguished between material, thematic, and technical 'Bedeutungsvorstellungen', lit. 'meaning-ideas'. He connected thematic and technical semantic images to 
music. Material semantic images are, according to Volkelt, linked only to visual arts and its perception; that means such arts that refer to actual/existing (skutečný) meanings. That is why music never refers to anything but itself; thus, there are no conditions for material semantic images to be created.

Material semantic images are, according to Volkelt, images of 'things'; therefore, they must refer to concrete objects. Thematic semantic images are connected to material the artist worked with to create their art work. As related to music, Volkelt speaks about pitch, volume, timbre etc. Technical semantic images are images of the process. In other words, we may call it the technique and/or method. In terms of music, we speak about the placement of each tone as a part of a whole piece, technical aspects etc.

When both attitudes are compared, several distinctions appear. Zich adopts the distinction between individual semantic images, yet he changes their meaning. The main difference with Zich lies in his interconnection of material semantic images and music, which Volkelt refused. Such a difference is rooted in a distinct understanding of the term. Volkelt grasps material semantic images as non-musical semantic images, whereas Zich understand them as purely musical images, namely as musical individualities in their factuality. However, both Volkelt and Zich refused to include non-musical associations in the aesthetic perception of music. Zich's concept of technical semantic images as superior to material and thematic images also differs from Volkelt's perspective.

\section{The Types of Poetry (1918)}

Zich's The Types of Poetry is an important work for the purposes of this article; as it also includes his theory of images. In this case, he omits the word 'semantic' and works simply with 'images'. Language, as a material from which poetry has been built, is based on the difference between the phonetic form of a word and its meaning. Zich mentions the sense of words rather than their meaning in order to strictly distinguish between them. Therefore, the difference between 'an idea and its verbal expression' has been pointed out. Terminologically, Zich identifies pure 'images' in poetry as opposed to musical semantic images. This aesthetic is an important step towards his theory of drama and theatre.

A recipient's images, based on the perception of poetic works, have two categories according to Zich. He distinguishes between 'images' linked directly to words, and 'mediated images' linked to their meaning. Zich then categorizes meditated images according to sense (smell, sight, sound, etc.) - the character of which these images adopt. Zich's system is thus dual in terms of its semantic level. First, there is the meaning of individual words; second, there is the meaning of a sentence he calls 'a poetic idea' (myšlenka). Thus, the meaning(s) of individual words form and complete the idea to be expressed. The associative power of poetry is, according to him, a specific quality of poetic language which he labels as 'mood' (náladovost). Mood is partly formed by images. Each and every image bears a certain mood. Interpreting Zich's point of view 
then, all images linked to a certain word also create a set of moods, which is the key essence of the 'mood'.

These images are central to the system in question. Zich determines his view of poetic semantic images even in Aesthetic Perception of Music, the most important definition of which states:

Should such a semantic image in visual arts be a result of a concrete percept, it becomes an aesthetic object in poetry. Poetic words - be them read, or spoken out - are means of provoking a number of images in our imagination; yet, some kind of aesthetic meaning of these words and their sound cannot be denied. (ZICH 1981: 156)

A crucial aspect of this definition is Zich's emphasis on semantic images. According to him, they become 'an aesthetic object'4. The form of 'an aesthetic object' is, in case of material artistic artefacts, clear and obvious. Music is represented by an acoustic perception, whereas a literature artefact is necessarily immaterial and adopts the form of an acoustic percept. Recipients sense words which do not have as an immediate impact as music. Such immediate impact is not of high importance. Verbal signs need to be semantically decoded by assigning the particular meaning to certain word(s). Only then may we perceive the meaning of what has been said. That is why Zich attributed the dual aspect to poetic images based on percepts.

Zich also credited the acoustic quality of verses with aesthetic value. This was highlighted by Oleg Sus, who saw it as a connection between Czech literary science and Russian formalism, which was primarily interested in the phonetic quality of spoken words. Sus also discussed their differing perspectives; while Russian formalists based their theories on linguistics, Zich based his on musicology. That is also the reason for Zich ascribing aesthetic quality to the acoustic form of words; thus, he was able to measure the immediate effect of acoustic perception.

Another of Zich's comments on poetic aesthetics in Aesthetic Perception of Music states:

We only perceive signs - written, printed, or spoken words in poetry, yet our imagination has to create aesthetic objects. Words such as 'love' or 'Prometheus' may connote a whole range of images, some less (or none - just like 'Prometheus'), some more. The latter build the aesthetic object in poetry.' (ZICH 1981: 186)

Zich explains: 'An aesthetic object' may be easily identified with the 'aesthetic object in poetry'. According to Zich, aesthetic objects are equal to images created in the recipient's imagination on the ground of words received either in acoustic form. The passage on 'aesthetic object in poetry' is followed by: 'Next to purely acoustic, rhythmical qualities of poems.' (ZICH 1981: 187)

4 We keep in mind fact that Jan Mukařovský gave a new meaning to a term aesthetic object (MUKAŘOVSKÝ 2007a) in 1934, year of Zich's death, but Zich obviously used this term in used in a simpler way. Thus we understand this term in a more general way. 
This demonstrates that Zich thought of both qualitative levels of words - acoustic and semantic - as equal.

Zich divides the acoustic qualities of poems into two categories: "poetic acoustic qualities', which are the qualities rooted in poem themselves; and 'declamatory acoustic qualities', dependent on recitation. Included are specific acoustic qualities (zvuk hlásek) such as, timbre, rhythm, intensity of speech, tempo, and melody. According to Zich, these qualities cannot be replaced by musical qualities. Zich bears in mind the individual character of each art form; it is him who points to the impossibility of such exchange:

\begin{abstract}
'Musical quality or musicality' of verses and/or prose is useful to a certain extant; it labels their quality as acoustic, as opposed to the semantic quality of poems. We can accept such a description; yet, the person to use it has to bear in mind that he/she is literary speaking, using a term only borrowed from a different art form, which does not express or touch identity [...]. Musical quality does not mean a set of high tones like in melody; it means a set of sounds with regard to their colour. It is a phonic quality, not a tonic one. (ZICH 1937: 34)
\end{abstract}

A performative way of reciting is of high importance to Zich. He often takes the reciter of a poem as someone who should partly become an 'actor' - he speaks about an 'artist' and the creative qualities to be applied in recitation:

He can and should fully expose his artistic qualities and represent not only the poet but himself too, his concept of and approach to the piece of art [...]. Thus, a problematic question arises: To what extent is the reciter also allowed to add mimic expressions? Yet for our current purposes, we may omit the answer. (ZICH 1937: 18)

Zich still accepts the distinction between actor and reciter.

Zich understands performativity as a crucial aspect of poetry's realization in time. In the following definition, he expresses his performative understanding of poetry; he states: 'The poem earns its existence in and due to recitation; therefore, the reciter is the one to complete the poem's journey, much like a musician or an actor.' (ZICH 1937: 18) Zich obviously ascribes a crucial part of poetic artefact to recitation. This assumption has a crucial impact on Zich's theory of poetry. He finds the 'poetic indulgence' complex, much like a piece of music is formed by musical and verbal contents: 'My attention is drawn to a strong rhythm at some point, and then to a suggestive image or for instance to the musical sound of words.' (ZICH 1937: 19)

Jan Mukařovský, in his study 'On the Art of Reciting' (O recitačním umění), published in the journal Program $D 47$ (1946), describes the contemporary performance of poetry. Mukařovský focuses on the historical development of reciting poetry and highlights the shift in reciting style as it occurred at the end of the $19^{\text {th }}$ century:

There was nothing like a recitation as a specific genre of verbal arts till 1890s. It was simply understood as a specific kind of theatre declamation. An actor was performing the verses, 
and the poem he was acting became a dramatic monologue, part of a 'role'. Its declamation differed from a theatrical performance only in terms of absence of any theatrical mask, production, or dialogue. At the end of $19^{\text {th }}$ century, this kind of poetic declamation radically changed. (MUKǍ̌OVSKÝ 2007b: 429)

Theatre was then seen as subordinate to literature (the concept of drama as literature); yet in practical terms, there was also an opposite direction leading from declamation to theatre. A dramatic text was seen (even when Zich was writing) as a product of dramatic poetry.

Zich's view of poetic recitation may be taken as an example of a shifting view of a relationship between theatre and poetry. Zich points to the distinction between the actor and the reciter even on the level of mimics, but does not do it clearly and systematically. Mukařovský discusses Zich's conception of:

[Zich] distinguished between textual acoustic qualities and 'reciting' or open acoustic qualities. According to Zich, the textually unbound qualities include the strength of exhalation, tempo, and 'melody of speech' - the qualities we know today to be to a large extant given by the text itself. Yet, he was the first to make the distinction, which was later on adopted and completed due to structural linguistics by structuralistic theory of poetry. (MUKǍ̌OVSKÝ 2007b: 432)

Zich defined the following components of a poetic work: perception (smyslový činitel), everything in a recipient's mind based on this perception (reprodukčni činitel bezprostredni), and everything created in recipient's mind as a reaction to the previous perception, (reprodukčni činitel zprostredkovaný). The first component includes speech and its rhythm.

The section on the second component (reprodukčni činitel bezprostředni) begins with an analysis of the spoken word and its relation to meaning. Zich used terms such as sign, images, and meaning:

[...] certain groups of sounds and syllables are significant for particular images or terms. The spoken text is thus divided into certain groups - words - and images linked to them, which influence the meaning of words, sentences, and sentence structure we called 'poetic ideas'. (ZICH 1937: 42)

There is a link between the word and its meaning, which humans learn to make by repetitions, which then starts to create an automatic connection in the mind. In this context, Zich thinks of signs and their meanings (Zich uses the term 'sense' of a word, not 'meaning'); he points to the fact that a particular word refers to a certain meaning it represents. Zich has added there are usually a number of individual images related to one single word.

Zich tries to define the specificity of poetic words and uses the term 'mood': 'The difference between poetic language and casual language, even scientific language, lies 
in the unusual mood of its words, which is caused by those images that link to a certain word; thus, it becomes a function of verbal "meaning”.' (ZICH 1937: 43) Interpreting Zich's argument, the specificity of poetic language is rooted in its associative power, which elicits a number of emotive images in recipients' minds. In order to highlight this emotiveness, Zich uses the example of words with a strong emotional connotation; e.g. mother, love, heaven, Czech and dead. He even speaks about an 'emotional radiation', calling mood the 'function of verbal meaning'.

Zich also defines the meaning of sentences, which he terms 'ideas'. He deconstructs these ideas from their verbal expressions:

The ideas a poet aims to express have their mood independently on the words used. Let me call it an intellectual mood. Poetic ideas do live in many cases, so to say, their own life and are embodied into individual poetic works distant both in space and time.' (ZICH 1937: 48)

The crucial part of Zich's comment on 'everything created in recipient's mind as a reaction to the previous perception', is centred on recalled images and the associative possibilities of words. Zich speaks about 'images, which are not linked to the perception but to the sense of words and sentences' (ZICH 1937: 51). According to Zich, poetic language has the ambition to create illustrative images or, in other words, their visualization according to their primary sensual character.

Zich first characterizes 'visual images' as 'images' our imagination offers when we read a poem' (ZICH 1937: 53). Their main characteristics are subjectivity and vagueness. Zich pays special attention to the images of movement, the reason of which is the recipient's motor reaction.

In Zich's opinion, 'acoustic images' differ from direct acoustic percepts that are experienced while listening to a poem. They must be recalled on the grounds of verbal meaning. This occurs primarily in case of direct speech included in the poem, or in case of words connected to human acoustic expressions (such as crying). The third group, next to visual images and acoustic ones, is represented by 'images of lower senses' (smell, taste, touch). The last category is formed by 'internal-haptic and motor images' - a category highlighted by Zich because of the high frequency of such images.

Zich finds the kinaesthetic qualities of percepts in poetry important. He states:

Rhythm has a motoric effect - this fact is pretty well known. People tend to (unwittingly) imitate any felt rhythm with physical movements (primarily breathing). It is not necessary for us to really move, the so-called innervations are more than enough. Innervations are muscular sensations we have the second before we actually do move. We are interested in the rhythm of speech; therefore the movements of organs of speech are of highest importance here. We may therefore conclude that a poem's rhythm is primarily of a spoken (mluvni) quality. (ZICH 1937: 37)

Concluding The Types of Poetry, Zich defends the formal qualities of poems, at the expense of their contents, which, according to him, should be part of a non-artistic 
sphere. This attitude is also present in Aesthetic Perception of Music, where he divided components of aesthetic perception into artistic and non-artistic. Thus, the contents of a poem are assigned to the non-artistic sphere:

It would be incorrect to think that an artistic value of a poem depends primarily on the value of ideas. A poetic idea as such may be of moral, religious, and social value. Yet, this quality necessarily stays non-artistic and neither intensifies nor decreases a real aesthetic value of an artwork. We often find such qualities/values in literary, yet non-poetic works. (ZICH 1937: 90)

Importantly, he also states: 'We may find similar, even more important ideas in philosophical works, which we never consider as poetic.' (ZICH 1937: 90)

Zich considers the form of a poem to be of artistic value. Its contents and ideas are separated and categorized individually. The reason for such a method is that Zich does not count contents as a specific characteristic of poetry because there are a number of non-poetic literary works with the same quality. The specific value of poetry then, lies in its form and setting. Both this opinion, and his denial of music's non-musical values, show his persistent connection to 'Herbartian formism'.

Zich's aesthetics of poetry connects his theory of music to that of drama and theatre. His theory of musical semantic images is close to Volkelt's point of view but less semiotic, as Zich argues that music does not refer to anything but music. Nevertheless, it is a starting point for him to examine the semiotic tendencies of artworks. His theory of semantic images in theatre is close to theatre semiotics. Poetry acts as a link between these theories and moves Zich towards semiotic thinking, because language is a highly semantic system. Zich does not use 'semantic image' but simply 'image' in The Types of Poetry; however, when he comments on poetry in his earlier Aesthetic Perception of Music, he uses 'semantic images' as a term in connection with poems.

Zich distinguishes between images linked directly to words, and mediated images linked to their possible meanings and associated images. In this particular sense, they become close to semantic images as Zich defined them later in The Aesthetics of Dramatic Art. We may identify here the predecessors of the concept of the visual semantic image, which, according to many scholars dealing with Zich, precede verbal semantics.

\section{The Aesthetics of Dramatic Art (1931)}

This book was the culmination of Zich's long-term research into the theory of theatre. During the winter of 1913-1914, Zich held a series of lectures titled: 'A Theoretical Dramaturgy', at Charles University, Prague. It is also a subtitle of this book. Without original lecture notes, it is impossible to ascertain whether the arguments presented in Zich's book of 1931, were the same as those offered to his students almost two decades earlier, in 1913-1914. It is, however, highly unlikely in this writer's opinion. Yet, this shows that Zich had had an interest in theoretical dramaturgy from at least 1913 onwards. Zich systematically uses the term 'dramatic art' instead of 'theatre' within 
the book. The reasoning behind the use of the term was that theatrical forms such as pantomime or dance were forms Zich found non-dramatic.

The Aesthetics of Dramatic Art brought about the first systematic theoretical approach to theatre in the Czech context. Zich understands an art form as a structure, and emphasises a scenic realization of a dramatic work, thus making dramatic art an art form, which is enclosed in its temporality. Zich focuses on the recipient's perspective, as in his previous studies of art forms in his previous books.

All the art forms Zich discusses and defines have one characteristic in common: their temporality. They all share the acoustic perception, which is accompanied with visual perception in case of dramatic art. An internal-haptic perception is also present in all these art forms.

Zich finds motoric percepts very important. They are as crucial for the perception of an actor's work as both acoustic and optic percepts:

When we observe other people, be it in everyday life or on stage, we tend to recall our motoric experiences without even noticing it. The more we put oneself in their place, which happens often in theatre, the stronger our motoric reactions are. Sometimes, we do not recall just motoric images but we may be forced to imitate what we see and hear, only partially, in a form of the so-called innervations. It is the motor component that adds liveness, irresistibility, and activity to our percepts. The 'dramatic' impression is characterized not only by acoustic and visual components but also by motoric percepts which provoke our physical organism. (ZICH 1986: 39)

The theory of semantic images is primarily connected to the theoretical reflection of the actor's work in Aesthetics. Zich point to the duality of image linked to the percept of a person that exists on stage; thus, he defines the dramatis persona:

From a noetic perspective, such a 'person' - be he/she in everyday life or in a drama, is something we in our mind add to the optic and acoustic percepts. $\mathrm{He} / \mathrm{She}$ is a pure image that we add to this appearance (percept) as a stable and lasting essence (substance) [...]. Due to this addition, this image and our percept make this persona seen (názorný). (ZICH 1986: 36)

Zich thus explains the term 'person', in general, as a certain image of individual essence we add to the perceived human being who looks and behaves in a particular way. We then add this set of characteristics to his/her 'picture' ('fond'). Only then are they perceived as a complete unit.

As opposed to perception in everyday reality, when we perceive an actor performing a certain character, we, according to Zich, do not only create an image as a reaction to the question 'what is it?', but we also add a semantic image based on our knowledge that this person is simply performing, that he/she adopted a certain role. Zich calls this knowledge a 'theatrical experience'. Such an experience is one of the so-called aesthetic preparations of mind (ZICH 1921). 
Zich approaches the semiotic concept of theatre in the following passage:

We can see that there is a difference between a semantic image of a dramatic person and a real human being. The question this dramatic person answers is not 'what is it' but 'what does this figure, which we perceive, represent or depict?' [emphasis, $D L$ ] Let me call this person a semantic visual image. The semantic image of the actor which is rooted in our knowledge of theatre and its artistic practices should be named the semantic technical image. [...] It is characteristic of an artwork that perceiving it, we do create two different semantic images simultaneously: a semantic technical image and a semantic visual image. (ZICH 1986: 43)

Such a depiction, of two different levels of perception regarding the actor's work, defines the duality of stage existence. Zich's concept of semantic images fulfils the basic semiotic demand of the sign - to refer to something other than itself.

Zich defines two terms parallel to the semantic technical image and semantic visual image: the dramatic person and the actor's figure. The actor's figure is defined as 'actor's work' and as a 'formed actor' (zformovaný). Zich elaborates on the distinction between the performing actor, and the meanings the spectator(s) add to the actor's performance. As Zich states: 'This image and our percept make this persona seen (názorný).' Such objectivity is, in this context, understood as the sensual quality of an image. The perception is due to both acoustic and visual percepts. Zich's distinction is at first glance surprising because of the fact that Zich began his enquiry in the context of realist theatre at the turn of the $20^{\text {th }}$ century.

Zich also comments on the chance of replacement:

It could happen that the actor's figure is identical with the actor. That would be a mistake caused by the fact that the material actor's work, e.g. 'dramatic person', is actor himself. Just like marble is not yet a statue and needs to be shaped to a proper form, a person exists in the 'formed actor'. Yet, the difference lies in the formation which is done here by the actor himself, who is thus both forming, and formed. (ZICH 1986: 45)

Zich explains this dimension with a structural unity: 'Concerning the structure, there is a match between "character" and "person". We will call this fact (valid for all visual arts) the correspondence principle between technical and visual semantic image. It is tails and head of the same fact [...].' (ZICH 1986: 46) Zich finally offers a basic definition based on previous argumentation: 'The actor is an artist who represents the imagined person through his own body.' (ZICH 1986: 48)

The distinction between 'dramatis person' and 'actor's figure' lies in the objectivity related to each term: 'Only [actor's figure] is objectively present on stage and does exist there, unlike dramatis person who exists in our minds, in our conscious, and thus only subjectively.' (ZICH 1986: 92) Also: 'We may use an abbreviation to point out the difference between them. Thus, the actor's figure is simply physiological, whereas the dramatis person is psychologically based.' (ZICH 1986: 45) Further 
on, he extends his definition: 'Shortly: the actor's figure presents for the actor a state of mind he is in while performing; therefore, it must be of psychological base. The actor's figure is of a dual shape: primarily physiological, secondary psychological.' (ZICH 1986: 109)

Zich also states: 'Purely in the actor's point of view, e.g. without contents of the spoken word, a dramatic person means to the audience a sum of all the visual and acoustic percepts.' Zich distinguished several types of semiosis he then describes as follows:

The imaginative power of language (disregard of the speech) is in this respect the strongest. $[\ldots .$.$] The centre of expressive function of language is in its ability to communicate the content$ of images - an idea, a thought which is what neither mimics nor music can do; and if so, then just partially and indefinitely. Therefore, speech and mimics complete each other in a dramatic work; it is only their combination that can evoke a perfect, complete visual image in the audience. (ZICH 1986: 103)

This kind of distinction led Zich to a three-dimensional characteristic of the dramatic person: 'The dramatic person seems to be the resulting product of three synthesis done by the audience, two of which are linked to the actor, the last one lies in the contents of speech written for this figure by the author. The actor's characteristic is either static or dynamic, according to its realization: either due appearance and costume, or due to speech and action'. (ZICH 1986: 104)

\section{Conclusion}

The common methodological denominator of these texts is the aesthetic exploration of art works (including their entity and structural arrangement); and the connection between aesthetic and psychological-(semiotic) exploration.

Zich based his research on the spectator's perspective even in his first complex study, The Aesthetic Perception of Music. It seems that the specifics of music material required such a method, which is otherwise difficult to grasp and define. Even though the spectator's approach to aesthetics existed before Zich, it was Zich who emphasized the relation between those two parts of aesthetic perception, and asked for its 'objectivity' to be kept. The same method is to be found in The Types of Poetry and Aesthetics. In Aesthetics, such a method resulted from Zich's view of theatre as an autonomous art. The Types of Poetry include both thoughts and methods; Zich paid a lot of attention to the acoustic quality of words (their musicality) as well as to the performative concept of poetry (its theatricality). These qualities, which Zich attributes to poetry, stem from the recipient's point of view.

Zich's emphasis on motoric impacts of aesthetic perception is probably rooted in his musicological system. Musical material led him to research the recipient's psychomotoric reactions to the received 'aesthetic object' and its effect on the recipient. Zich was inspired by the theory of empathy which existed in German aesthetics, namely in works by Theodor Lipps or Johannes Volkelt. According to Petr Kaiser (KAISER 1993: 
85), the theory of empathy formed the basis for Zich to accept the recipient's perspective as central to the analysis of arts.

Zich develops the concept of 'semantic images' within his works. The term connects a psychological notion of 'image', the mental phenomenon created in human mind, and 'meaning' as a part of semiotics. I found that in general, 'semantic image' is, put simply, 'the meaning of something, that is perceived'. This is also the meaning of the term in the context of linguistics. It is based on, and exists due to, complex and difficult mental processes in the human mind, which verbalize perceived reality. This verbalization does not occur in every case. If we do not have a verbal term for a perceived phenomenon, its perception is simply immediate. Zich then defined several categories of the term in connection with a particular art form.

In Aesthetic Perception of Music, Zich distinguishes between three kinds of semantic images: thematic, material, and technical. The term 'semantic image' is not used in Zich's work The Types of Poetry, which simply uses the term 'images'. The Aesthetics of Dramatic Art then uses 'semantic visual images' and 'semantic technical images'. Semantic visual images as viewed by Zich are the precursor of semiotic perception, as the 'multiple-leveled meaning' in its semiotic sense.

There is a huge gap between semantic images as defined in Aesthetic Perception of Music and those later in The Aesthetics of Dramatic Art. Zich refused to accept non-musical images as a part of the aesthetic perception of music. Semantic images in this sense thus refer only to music itself. There is a lack of any semiotic connection in the sense that a sign has to refer to something other than itself. Semantic images in music are not, according to Zich, linked to a particular aspect of the work perceived, but shift from one layer to another, whether these layers are qualitative or quantitative. This view stems from music's specificity. Semantic images connected to dramatic artworks are always two sides of the same percept. From a modern standpoint, we would speak of a sign and its meaning.

Both The Aesthetics of Dramatic Art and Aesthetic Perception of Music include the 'semantic technical image'. According to Zich's definition of semantic image in The Aesthetics of Dramatic Art, we find a of the semantic technical image even in Aesthetic Perception of Music, even though the concept is not yet named so. The 'semantic technical image' is the image of a certain art form, e.g. a painting, a building, a statue etc. With regards to acting, the 'semantic technical image' is the actor in their role. In the case of music, the semantic technical images would be general images linked to the structure of compositions, e.g. articulations, composition type, key and time signatures, etc.

Zich's interpretation in The Aesthetics of Dramatic Art, signifies that in the so-called visual arts, which represent something (in modern words: arts, which enable semiosis), a particular semantic technical image corresponds to a certain semantic visual image. Even though Zich qualifies music as a non-visual art form, it can still bear musical meanings.

The Types of Poetry include the characteristics of both music and dramatic art. The work is also crucial to Zich's semiotic perspective. The division of perception as everything in a recipient's mind based on this perception (reprodukčni činitel bezprostredni) and everything created in recipient's mind as a reaction to the previous perception 
(reprodukčni činitel zprostředkovaný) goes further than his autosemantics (a term used by Oleg Sus) and shows Zich's inclination towards reflection of theatre semiosis.

Zich adopted the term semantic image from Johannes Volkelt whose influence on Zich can be strongly felt in Aesthetic Perception of Music. Zich's work however, presents remarkable shifts from Volkelt's perspective. The Types of Poetry clearly demonstrates Zich's tendency to approach the artistic material and its perception from a semantic viewpoint. He does not distinguish between thematic, material, and technical semantic images, but defines individual aspects of the semantic field of poetic language. The Aesthetics of Dramatic Art presents the result of Zich's long-term thinking on semantic images. He devised 'semantic visual images' and 'semantic technical images' in the work. This concept, based on the specificity of theatre and drama, is far from the first definition offered in Aesthetic Perception of Music. The Aesthetics of Dramatic Art later became a crucial part of theatre semiotics and meant a turning point both in Czech theatre studies.

The intention of this article is to interpret Zich's work through detailed analysis. Literature about Zich in English language is quite sparse. For example, Peter Steiner pointed out in his book that an influence of structuralist theories on Zich's writings is overrated, and that we should search for his scientific roots most likely in psychology (STEINER 1982). Thomas Winner was another scholar who dealt with the same issue (WINNER 1989). He regards Zich's theories as the predecessor of structuralism and semiotics (The Prague School). Equally he realized same impossibility of interpreting Zich's theory as exclusively semiotic. Emil Volek supports a similar opinion: 'attempted semiologization of the correlation is not completely wrong, but is not right either' (VOLEK 2012: 176). Thus, it is necessary to accept Zich's unique position in history of Czech art theory.

\section{Bibliography}

DYKAST, Roman. 2008. Otakar Zich - Jaroslav Hruban, estetikové z Hostinského školy [Otakar Zich Jaroslav Hruban, Aestheticians from Hostinský School]. 1. vyd. Praha: Společnost pro estetiku a Katedra estetiky při FF UK v Praze, 2008.

KAISER, Petr. 1993. Protostrukturalismus v české estetice a literární vědě, básnická typologie Otakara Zicha [Post-Structuralism in the Czech Aesthetics and Literary Studies, Poetic Typology by Otakar Zich]. Česká literatura. Časopis pro literární vědu 41 (1993): 1: 83-9.

MUKAŘOVSKÝ, Jan. 1933. Otakar Zich: Estetika dramatického umění [Otakar Zich: The Aesthetics of Dramatic Art]. Časopis pro moderní filologii a literaturu XIX (1933): 318-9.

MUKAŘOVSKÝ, Jan. 2007a. Umění jako sémiologický fakt [Art as a Semiological Fact]. In id. Studie I [Studies I]. Miroslav Červenka and Milan Jankovič (eds.). Strukturalistická knihovna, svazek [volume] 4. Brno: Host, 2007a: 208-14.

MUKAŘOVSKÝ, Jan. 2007b. O recitačním umění [On the Art of Declamation]. In id. Studie $I$ [Studies I]. 2. vyd. Brno: Host, 2007b: 428-41. 
OSOLSOBĚ, Ivo. 1981. Sémiotika sémiotika Otakara Zicha [The Semiotics of Otakar Zich, a Semiotician]. In Rudolf Pečman. Vědecký odkaz Otakara Zicha: sbornik ze sympozia v Praze (16.18. května 1979) [Scholarly Legacy of Otakar Zich: Proceedings from the Prague Symposium (16-18, May, 1979)]. 1. vyd. Brno: Česká hudební společnost, 1981: 37-52.

OSOLSOBĚ, Ivo. 1986. Zichova filozofie dramatického tvaru [Zich’s Philosophy of Drama]. In Otakar Zich. Estetika dramatického uměni [The Aesthetics of Dramatic Art]. 2. vyd. Praha: Panorama, 1986: 373-99.

OSOLSOBĚ, Ivo. 2007. Herecká postava - pro a proti [Actor's Figure - pros and cons]. In Principia parodica, totiž, Posbirané papíry převážně o divadle [Principia parodica, or The Collected Papers Mostly on Theatre]. 1. vyd. Praha: Akademie múzických umění, 2007: 202-18.

PEČMAN, Rudolf. 1981. Vědecký odkaz Otakara Zicha: sborník ze sympozia v Praze (16.-18. května 1979) [Scholarly Legacy of Otakar Zich: Proceedings from the Prague Symposium (16-18, May, 1979)]. 1. vyd. Brno: Česká hudební společnost, 1981.

PEČMAN, Rudolf. 1981. Zichova „významová představa' a tzv. „asociační zákon’ Františka Krejčího [Otakar Zich's 'Image of Meaning', and František Krejčí’s 'Association Law']. In Otakar Zich - Jaroslav Hruban, estetikové z Hostinského školy: [sbornik z konference] [Otakar Zich - Jaroslav Hruban, Aestheticians from Hostinský School: Conference Proceedings]. Vyd. 1. Brno: Tribun EU, 2008. Knihovnicka.cz. 16-31.

PROCHÁZKA, Miroslav. 1988. O povaze dramatického textu [On the Nature of Dramatic Text]. In Znaky dramatu a divadla: studie $k$ teorii a metateorii dramatu a divadla [Characteristics of Drama and Theatre: Studies to Theory and Metatheory of Drama and Theatre]. 1. vyd. Praha: Panorama, 1988a: 11-30.

PROCHÁZKA, Miroslav. 1988. U základů sémiotiky divadla [The Roots of Theatre Semiotics]. In Znaky dramatu a divadla: studie $k$ teorii a metateorii dramatu a divadla [Characteristics of Drama and Theatre: Studies to Theory and Metatheory of Drama and Theatre]. 1. vyd. Praha: Panorama, 1988b: 200-33.

STEINER, Peter. 1982. The Roots of Structuralist Esthetics. In id (ed.). The Prague School. Selected Writings, 1929-1946. Austin: University of Texas Press, 1982: 174-219.

SUS, Oleg. 1958. Sémantický problém „významové představy“ u O. Zicha a J. Vokelta: K počátkům sémantiky v moderni české estetice [The Semantic Issue with Zich's and Vokelt's Term 'Image of Meaning']. SPFFBU/Sborník prací filosofické fakulty brněnské university, řada uměnovědná F2, 1958: 99-116.

SUS, Oleg. 1992. Geneze sémantiky hudby a básnictvi v moderni české estetice: Dvě studie o Otakaru Zichovi [Genesis of Semantics of Music and Poetry in Modern Czech Aesthetics: Two Studies on Otakar Zich]. Brno: Filozofická fakulta Masarykovy univerzity, 1992.

SUS, Oleg. 2012. Průkopník české strukturně sémantické divadelní vědy (Psychosémantika a divadelní umění) [The Pioneer of Czech Structural-Semantic Theatre Studies (Psycho-Semantics and Theatre)]. Theatralia 15 (2012): 2: 218-43.

VOLEK, Emil. 2012. Theatrology an Zich, and Beyond: Notes Towards a Metacritical Repositioning of Theory, Semiotics, Theatre, and Aesthetics. Theatralia 15 (2012): 2: 168-86.

VOLKELT, Johannes. 1905. System der Ästhetik. München: C.H. Beck'sche Verlagsbuchhandlung, 1905. 
VYSLOUŽIL, Jiří and Jiří FUKAČ. 1997. Slovnik české hudebni kultury [Encyclopaedia of Czech Music Culture]. 1. vyd. Praha: Editio Supraphon, 1997.

WINNER, Thomas. 1989. Otakar Zich as a Precursor of Prague Literary Structuralism and Semiotics. In Issues in Slavic Literary and Cultural Theory: Studien zur Literatur-und Kulturtheorie in Osteuropa. Bochum: Universitätsverlag Dr. Norbert Brockmeyer, c1989: 227-42.

ZICH, Otakar. 1921. Estetická příprava mysli [Aesthetic Preparation of Mind]. Česká mysl XVII (1921): 150-62, 193-204.

ZICH, Otakar. 1937. O typech básnických [On Poetic Types]. Praha: Orbis, 1937.

ZICH, Otakar. 1981. Estetické vnímání hudby [Aesthetic Perception of Music]. 1. vyd. Praha: Supraphon, 1981.

ZICH, Otakar. 1986. Estetika dramatického umění: teoretická dramaturgie [The Aesthetics of Dramatic Art: A Theatrical Dramaturgy]. 2. vyd. Praha: Panorama, 1986. 


\section{Summary}

\section{Meaning(s) of Otakar Zich's Concept of the 'Semantic Image'}

This paper deals with Otakar Zich's concept of the 'semantic image'. The author analyses Zich's aesthetical studies to observe changes in his interpretation of this concept over time. On the basis of the thinking regarding this concept, Zich began to differentiate between semiotic layers of a work of art. So, we can consider him the forerunner of Czech semiotic thinking, with regards to art theory and aesthetics.

\section{Keywords}

Otakar Zich, semantic image, Czech aesthetics

DOI: 10.5817/TY2016-2-6

\section{Mgr. Dita Lánská}

Masaryk University, Brno, Czech Republic

E-mail: 342584@mail.muni.cz

Dita Lánská received her MA in Theatre studies from Masaryk University, Brno in 2013 with the thesis 'Development of the Otakar Zich's theoretical system: the significatory image and other aspects'. She is currently studying for her $\mathrm{PhD}$ at the Department of Theatre studies at Masaryk University. In her research, she focuses on theatre theory. Her study has an emphasis on the introduction of theatre theory in the Czech lands. 
